\title{
Impact of winter dense water formation on shelf sediment erosion (evidence from the Gulf of Lions, NW Mediterranean)
}

\author{
François Bourrin ${ }^{\mathrm{a}, \mathrm{c}, *}$, Xavier Durrieu de Madron ${ }^{\mathrm{a}}$, Serge Heussner ${ }^{\mathrm{a}}$, Claude Estournel $^{\mathrm{b}}$
}

\footnotetext{
${ }^{a}$ Centre de Formation et de Recherche sur l'Environnement Marin, CNRS, Université de Perpignan Via Domitia, 52 Avenue de Villeneuve, 66860 Perpignan Cedex, France

${ }^{\mathrm{b}}$ Pôle d'Océanographie Côtière de l'Observatoire Midi-Pyrénées-Laboratoire d'Aérologie, CNRS, Université de Toulouse, 14 Avenue Edouard Belin, 31400 Toulouse, France ${ }^{c}$ Observatoire Océanologique de Villefranche, Laboratoire d'Océanographie de Villefranche, CNRS, Université Pierre et Marie Curie, B.P. 08, 06238 Villefranche-sur-mer, France
}

\begin{abstract}
A 1-year survey of sediment dynamics on the Têt inner-shelf in the south-western part of the Gulf of Lions was conducted as part of the EUROSTRATAFORM program (European Margin Strata Formation) from October 2004 to November 2005. Several bottom instruments (ADCP, wave gauge and altimeters) were deployed at $28 \mathrm{~m}$ water depth on the Têt prodelta to measure forcing responsible for sediment erosion and transport on the inner-shelf.

The survey period was characterized by low inputs from the coastal rivers and the absence of severe E-SE marine storms, but intense cold dense shelf water formation along the inner-shelf due to strong and persistent N-NW continental winds. The strong $(>20 \mathrm{~cm} / \mathrm{s}$ ) and prolonged (4 months) southwards alongshore currents during the preconditioning and formation phases of dense shelf water generated continuous sediment erosion of several centimetres on the Têt prodelta and significant suspendedsediment transport. Hydrodynamical modelling shows that the core of the flow predominantly affects the inner-shelf, but occasionally spreads over the mid-shelf mud belt and the outer-shelf, due to the variable intensity of the NW wind (Tramontane).

The impact of this N-NW wind-driven process in terms of resuspension rates and suspendedsediment transport clearly differs from that of extreme E-SE storms observed during the previous winter at the same site [Guillén, J., Bourrin, F., Palanques, A., Durrieu de Madron, X., Puig, P., Buscail, R., 2006. Sediment dynamics during wet and dry storm events on the Têt inner shelf (SW Gulf of Lions). Marine Geology 234 (1-4), 129-142.]. Bottom shear stresses and resuspension rates due to strong dense shelf water flow peaked at $0.7-1 \mathrm{~Pa}$ and $0.3-0.4 \mathrm{~g} / \mathrm{m}^{2} / \mathrm{s}$, respectively, while they reached values of 6-9 Pa and $1.6-1.8 \mathrm{~g} / \mathrm{m}^{2} / \mathrm{s}$, respectively, during the strong E-SE storms events. However, due to differing durations, both led to significant (few centimetres) erosion of the inner-shelf sediment.
\end{abstract}

\section{Introduction}

Modern sediment dynamics on continental shelves are essentially dependent upon sediment inputs by adjacent rivers and hydrodynamic conditions. The number and strength of sediment sources, which are essentially active during floods, control the sedimentation rate on the inner-shelf and on prodeltas, the submarine part of continental deltas directly off the river mouths (Milliman and Syvitski, 1992). On the inner part of micro-tidal shelves, waves are generally considered the main stirring mechanism causing bottom sediment resuspension. The

\footnotetext{
* Corresponding author at: Centre de Formation et de Recherche sur l'Environnement Marin, CNRS, Université de Perpignan Via Domitia, 52 Avenue de Villeneuve, 66860 Perpignan Cedex, France. Tel.: +33493763717;

fax: +33493763739 .

E-mail address: fbourrin@obs-vlfr.fr (F. Bourrin).
}

wind-driven circulation then advects the sediment in suspension and control the bottom-shelf sediment distribution (McCave, 1972; Drake, 1976).

This general scheme applies to the Gulf of Lions (GoL) shelf, in the north-western Mediterranean Sea. The major sedimentary units (sandy inner-shelf and mid-shelf muddy belt; Fig. 1a) reflect the impact of waves on the inner-shelf and the south-westward dispersal of the sediment inputs from the Rhône River and the small coastal rivers by the cyclonic shelf circulation (Aloïsi, 1986). Recent observations (Ferré et al., 2005; Guillén et al., 2006; Palanques et al., 2006; Bourrin et al, 2008) and modelling (Ulses et al., 2008b) emphasized the role of severe E-SE storms. Their associated large waves $\left(H_{\mathrm{s}}>7 \mathrm{~m}\right.$ and $\left.T_{\mathrm{p}}>12 \mathrm{~s}\right)$ and currents create significant erosion over both the inner- and outer-shelf and subsequent transport towards the Cap de Creus Canyon at the SW end of the gulf. The E-SE storms have a marked seasonal impact with a maximum occurrence during autumn and winter. 


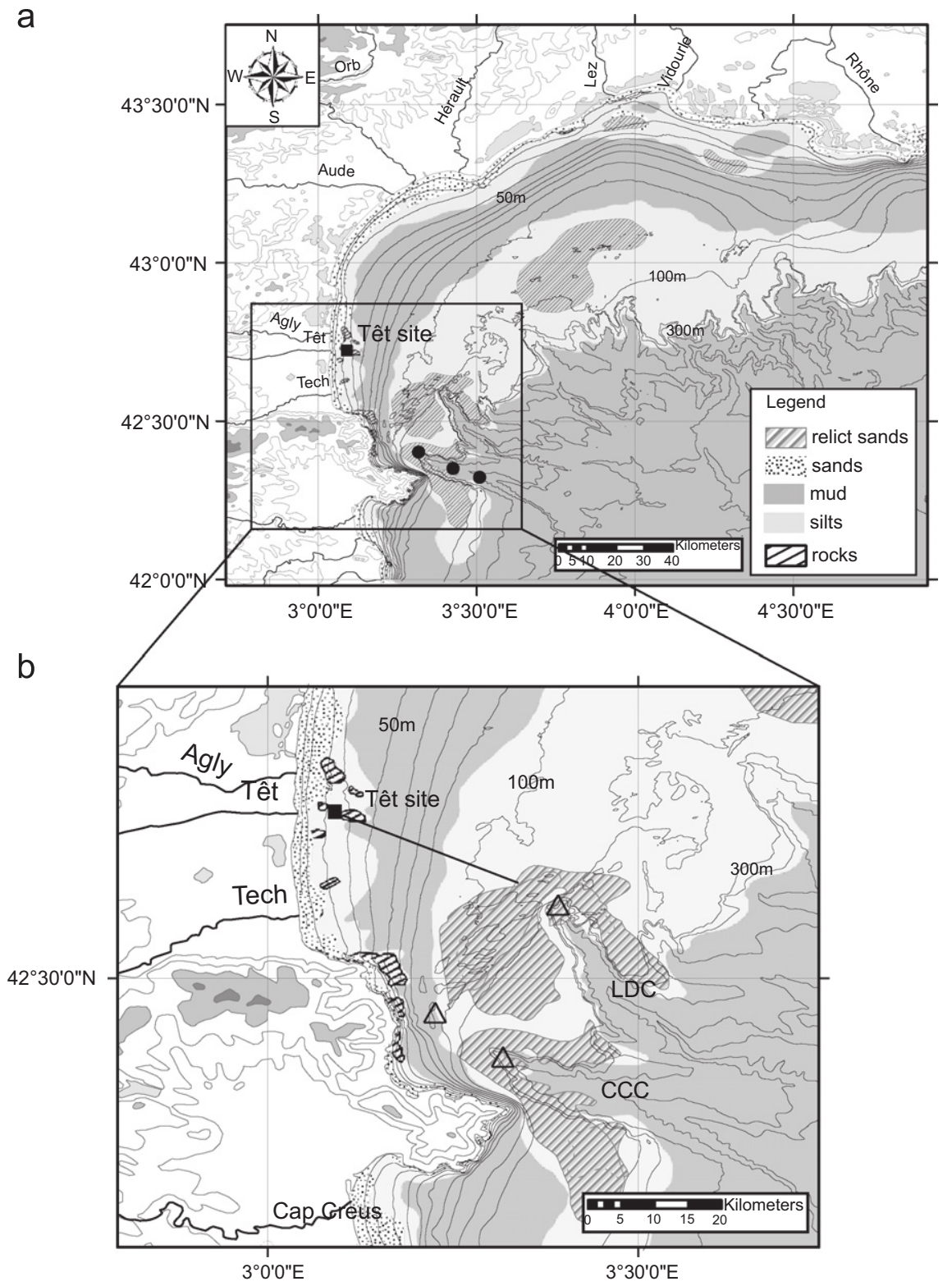

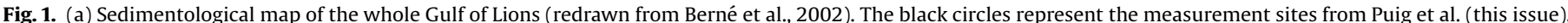

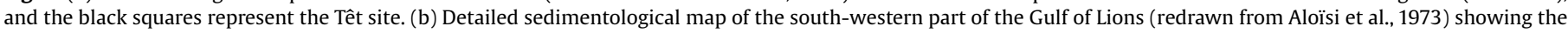

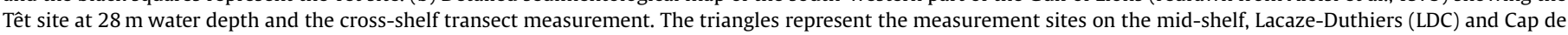
Creus Canyon (CCC) heads from Ogston et al. (this issue).

The autumn and winter periods are also characterized by the progressive disappearance of summer stratification and cooling of the shelf water by dry and cold N-NW continental winds, which eventually lead to the formation of coastal water denser than the offshore water (Dufau-Julliand et al., 2004; Ulses et al., 2008a). The cold dense coastal water forms a bottom-arrested gravity plume that propagates across the shelf and, once it reaches the shelf edge, cascades down the continental slope following topographic depressions to its horizon of equilibrium density. E-SE storms and dense shelf water transport can interact and enhance the off-shelf export, as shown by Palanques et al. (2006) and Ulses et al. (2008b), though they require opposite conditions to develop. River floods generally associated with E-SE storms decrease the salinity of surface waters and thereby limit the density increase of coastal water. Conversely, the strongest dense shelf water formations are observed for very dry and windy winters, which are not favourable to E-SE storms. During the winter of 2003-2004, large floods (20 years return interval) associated with extreme storms $\left(H_{s}>8 \mathrm{~m}\right)$ inhibited the formation of shelf dense water (Ulses et al., 2008a), whereas during the cold and windy winter of 2004-2005, the low river discharge and the persisting N-NW wind induced an unusually large formation and off-shelf export of dense water (Ulses et al, 2008c).

Dense shelf water formation is present on numerous continental margins (Ivanov et al., 2004), including northern Mediterranean margins like the northern Adriatic (Bergamasco et al, 1999) and the Thermaikos shelf (Estournel et al., 2005) in the northern Aegean. Though it has been hypothesized, the impact of dense water flow on shelf sediment dynamics has never been documented. This is particularly true for the GoL, where despite some earlier evidences of near-bottom transport of suspended matter by dense shelf water plume (Durrieu de Madron and Panouse, 1996; Lapouyade and Durrieu de Madron, 2001) and of massive down-slope transport through canyons (Heussner et al., 
2006), its effective impact on coastal sediment erosion and transport has not been explained thoroughly. In the present study, we assess the impact of the winter 2004-2005 dense shelf water flow on the coastal sediment dynamics, and compare it with the effect of large S-SE storms that dominated during the previous 2003-2004 winter. This paper is complementary to the study of Canals et al. (2006), Ogston et al. (2008) and Puig et al. (2008), who addressed the sediment resuspension and transport during this exceptional episode of dense shelf water formation further downstream, in and around the nearby canyons (Fig. 1).

\section{Material and methods}

A 1-year investigation of waves, currents, suspended-sediment concentrations (SSC) and fluxes, and bed-level measurements as well as sediment cores was conducted on the Têt inner-shelf, at the SW end of the GoL, from October 2004 to November 2005. It was part of a larger experiment designed to study the sediment dynamics on the shelf to the shelf edge and within nearby canyons (Fig. 1).

\subsection{Experimental site}

In the south-western part of the GoL, the sandy inner-shelf sediment is interspersed with rocky outcrops (Fig. 1b). The midshelf mud belt is centred along the $50 \mathrm{~m}$ isobath, and sandy patches appear between 100 and $200 \mathrm{~m}$ water depth around the Cap de Creus and Lacaze-Duthiers canyon heads. The experimental site is localized at $28 \mathrm{~m}$ water depth directly front to the Têt River mouth. The seabed is a flat bed composed of mixed fine sands and silts $\left(D_{50} \sim 80 \mu \mathrm{m}\right)$. No ripples were observed both in fair and storm conditions (Guillén et al., 2006). The grain-size is relatively constant throughout the year except after flood/storm events when ephemeral flood layers are deposited (Bourrin et al., 2007). Gastropods Turitella communis are common at the surface of the seabed and in the first centimetres of sediment.

\subsection{Wind and river discharge measurements}

The meteorological buoy of the "Plateforme d'Observation de l'Environnement Méditerranéen-Littoral Languedoc-Roussillon" (POEM-L2R), installed at $28 \mathrm{~m}$ water depth, $1.5 \mathrm{~nm}$ off the Têt River mouth $\left(42^{\circ} 42.210^{\prime} \mathrm{N}, 003^{\circ} 04.012^{\prime} \mathrm{E}\right)$, was the base site of the coastal zone monitoring (Fig. 1b). This buoy has a three-point helicoidal anchoring tightly linked to mid-water depth flotation to prevent any sediment resuspension (Fig. 2). This buoy shelters a seabed area allowing the deployment of benthic instruments and protecting them from trawling.

A Young Wind Monitor Model 05106 anemometer (RM Young Company), installed at $4 \mathrm{~m}$ above the sea surface on the top of the buoy, measured wind speed and direction every $15 \mathrm{~min}$. Data from the nearest Météo-France meteorological station in Torreilles (code 66212001, location $42^{\circ} 45.379^{\prime} \mathrm{N}, 02^{\circ} 58.781^{\prime} \mathrm{N}$ ) were used to fill the measurements gaps at the buoy site during maintenance. Hourly river discharge at the Têt River mouth next to the study site was obtained by adding the discharge of the Têt River measured at Perpignan (code Y0474030) and its last tributary, the Basse River (code Y0475610). These data, collected by "DDE de l'Aude", are available through the website of the National Data Bank "HYDRO" (http://www.hydro.eaufrance.fr/ accueil.html). Hourly river discharges of the Rhône River were measured by the "Compagnie Nationale du Rhône" (CNR) during the study period at the Beaucaire gauging station (code V7200010).

\subsection{Hydrodynamical measurements}

Currents and waves were monitored on the Têt prodelta at $28 \mathrm{~m}$ water depth from October 2004 to November 2005 using a $600 \mathrm{kHz}$ RDI upward looking ADCP equipped with a wave gauge, deployed on a bottom frame in the sheltered area of the buoy (Fig. 2). Two maintenance periods were necessary to change the battery and download the data in March (15-19) and July (6-22) 2005, defining three deployment periods over the whole year. High-frequency measurements of near-surface wave orbital velocities, surface track, and pressure were used to compute directional wave characteristics (RD Instruments, 2001). Waves were measured during 20 min bursts every $3 \mathrm{~h}$. Currents were measured at $1 \mathrm{~Hz}$ in $1 \mathrm{~m}$ depth cells from 2 to $27 \mathrm{mab}$, between wave burst measurements and were averaged every $3 \mathrm{~h}$.

\subsection{Hydrology, turbidity, and grain-size measurements}

Temperature was measured at the head of the ADCP instrument at the coastal site, at $28 \mathrm{~m}$ water depth. Conductivity, temperature, pressure data and turbidity profiles were collected during cruises on 10 October 2004 (R/V Oceanus) and 22 February 2005 (R/V Endeavor) along a cross-shelf transect between the coastal site and the shelf edge (Fig. 1b). CTD measurements were collected between the surface and the bottom, using a SeaBird 25 CTD probe. A Seapoint turbidity meter mounted on the CTD probe measured the light backscattering by suspended particles. Nearbottom water samples were collected and filtered up to filter saturation, on pre-weighed Nuclepore filters of $0.4 \mu \mathrm{m}$ pore size; their solid residue weights yielded SSC. Light scattering intensity ( $V$, in Volts) was converted into SSC (in $\mathrm{mg} / \mathrm{L}$ ) using the linear relation $\mathrm{SSC}=1.67 \times V+0.82\left(r^{2}=0.97\right)$.

A LISST type B (Sequoia Scientific) was deployed on the INSEECT tripod on April 2005 (Curran et al., 2007) and was set to take measurements every $15 \mathrm{~min}$ at $1.5 \mathrm{mab}$. Grain-size measurements of suspended material were investigated in the range $1.25-250 \mu \mathrm{m}$.

Sediment cores were sampled at the Têt buoy site at $28 \mathrm{~m}$ water depth by scuba divers using Perspex tubes $(20 \mathrm{~cm}$ long and $4 \mathrm{~cm}$ of diameter). Sediment cores were sliced at $1 \mathrm{~cm}$ intervals. Grain-size analyses were processed in laboratory using a Malvern Mastersizer 2000 particle size analyser equipped with a sample dispersion unit. Porosity was calculated using the measured total and dry weight after heating and the sediment density assumed to $2.645 \mathrm{~g} / \mathrm{cm}^{3}$.

\subsection{Estimation of SSC from backscatter intensities}

Acoustic backscatter intensities were measured by ADCP along the four transducers in depth cells of $1 \mathrm{~m}$ through the whole water column. Relative backscatter intensity is directly dependent of the quantity of suspended material in the water column (RD Instruments, 1996). The Sediview program (Land and Bray, 2000) was used to derive SSC from the average backscatter signal of the RDI ADCP using an iterative method to solve a simplified version of the sonar equation (Urick, 1975):

$\log _{10} M_{\mathrm{r}}=S\left[K_{\mathrm{s}}+\mathrm{dB}+2 r\left(\alpha_{\mathrm{w}}+\alpha_{\mathrm{s}}\right)\right]$,

where $M_{\mathrm{r}}$ is the mass concentration per unit volume at range $\mathrm{r}, S$ is the relative backscatter coefficient, $K_{\mathrm{s}}$ is the site and instrument dependent factor, $\mathrm{dB}$ is the measured relative backscatter intensity corrected for spherical spreading, $\alpha_{\mathrm{w}}$ is the water attenuation coefficient computed using measured temperature and salinity near the transducer, and $\alpha_{s}$ is the sediment attenuation coefficient. Information concerning the grain-size of 
a
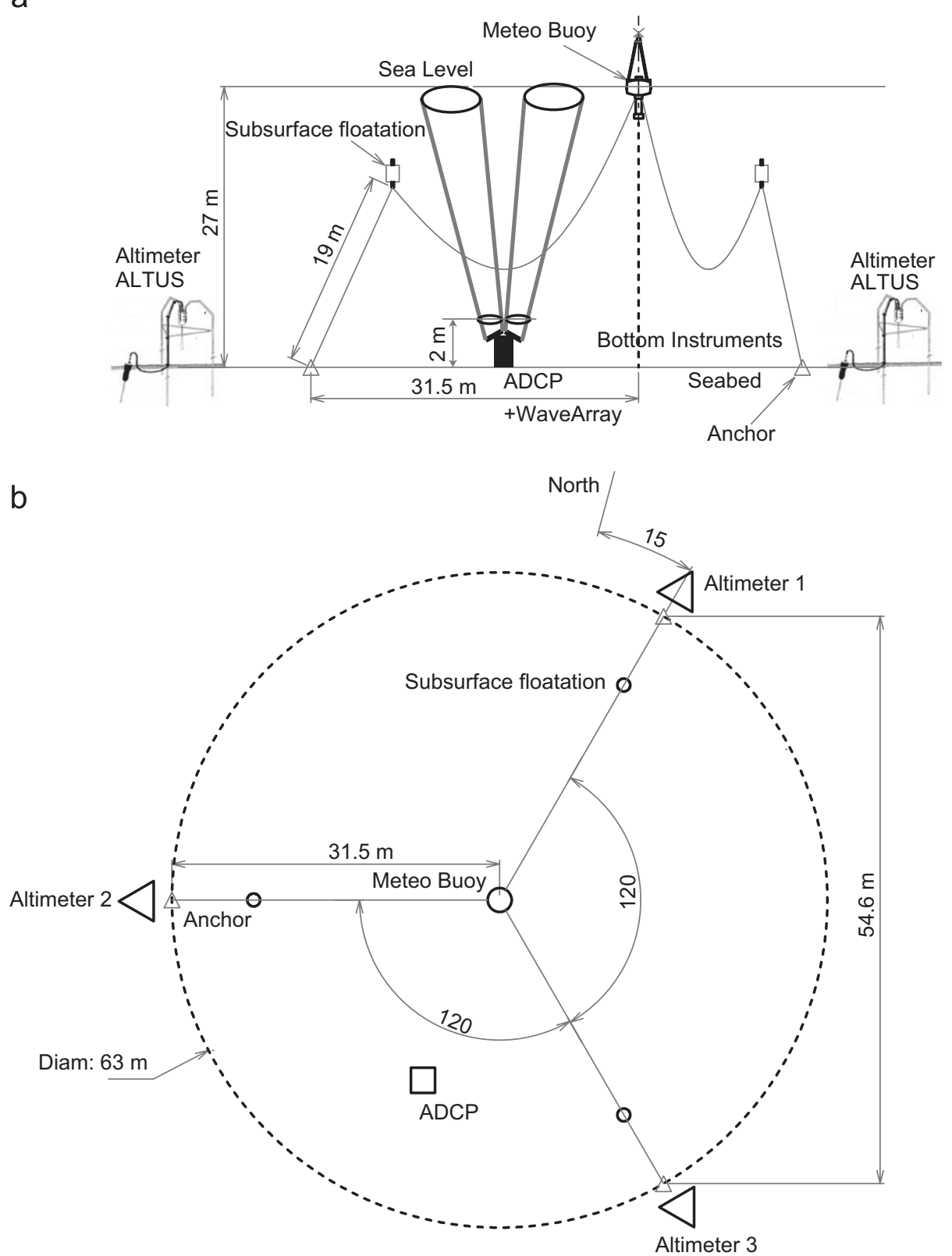

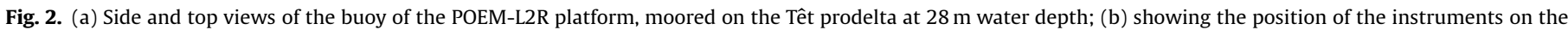
seabed (ADCP and altimeters) on the sheltered area of the buoy.

the suspended particles at the coastal site was provided by measurements from the LISST instrument. The calibration constants $S$ and $K_{\mathrm{s}}$ were determined by fitting the averaged backscatter intensities measured by the ADCP with the optically derived suspended-particle concentration profiles made next to the mooring site on October 2004 and February 2005. Fitted coefficient $K_{\mathrm{s}}=35$ and $S=25$ were used for the calibration of the data. Ferré et al. (2005) showed that the relative backscatter coefficient $S$ did not vary through time, but slight variations of $K_{\mathrm{s}}$ can be observed in relation to some changes in the nature of suspended particles.

SSC profiles were thus computed from 2 to 27 mab. This profile was extended between the bottom and the first cell of acoustical measurements ( $2 \mathrm{mab}$ ), using the Rouse equation, defining the vertical distribution of concentration $c$, in an open channel flow
(Rouse, 1937):

$\frac{c}{c_{\mathrm{a}}}=\left(\frac{h-y}{y} \frac{a}{h-a}\right)^{Z}$,

where $c_{\mathrm{a}}$ is the concentration at a reference level $y / h=a$ above the bed, $h$ is the total water depth $(28 \mathrm{~m})$, and $y$ is the height above the bed $(2 \mathrm{mab}) ; Z=w_{\mathrm{s}} /\left(k u^{*}\right)$ is the Rouse number, $w_{\mathrm{s}}$ is the particle settling velocity $\left(w_{\mathrm{s}}=0.2 \mathrm{~mm} / \mathrm{s}\right.$ for suspended particles of $226 \mu \mathrm{m}$ ) measured at the study site in April 2005 (Curran et al., 2007), $k=0.4$ is the von Karman constant. The shear velocity $u *$ is estimated from log-law velocity profiles derived from upward $\mathrm{ADCP}$ current measurements using the equation:

$u_{*}=\frac{k u(z)}{\log \left(z / z_{0}\right)}$, 
where $u(z)$ is the reference velocity at a height $z=h$ (flow depth), $z_{0}=0.033 k_{\mathrm{g}}$ is the bottom bedform height assumed to $2.6 \times 10^{-6} \mathrm{~m}$, and $k_{\mathrm{g}}=80 \mu \mathrm{m}$ is the grain-size at the seabed. SSCs above 20 mab were not used because of air bubbles that confuse the measurements close to the sea surface. Suspended-sediment fluxes were obtained from simultaneous current measurements and ADCP-derived turbidity measurements.

\subsection{Bed-level monitoring}

NKE Altus sonic altimeters were deployed at $28 \mathrm{~m}$ water depth at the buoy site to measure bed-level variations, during three consecutive deployments, from 30 September 2004 to 8 November 2005 (Fig. 1b). The Altus altimeter is a $2 \mathrm{MHz}$ acoustic altimeter with a transmitter/receiver transducer $\left(3.6^{\circ}\right.$ opening at $-3 \mathrm{~dB}$ ), with a $0.6 \mathrm{~mm}$ resolution and $2 \mathrm{~mm}$ accuracy. It is mounted on light tripod frame, whose legs were tightly screwed into the sediment, at $\sim 40 \mathrm{~cm}$ above the bed, hence preventing any sediment scouring under the transducer (Jestin et al., 1998; Bassoullet et al., 2000). Temperature measured by the nearby ADCP was used to estimate the change of the sound speed and correct the distance measured by altimeters between the transducer and the ground. Three altimeters were deployed by scuba divers next to different buoy anchors (Fig. 2a). Three deployment periods were necessary to measure the seabed level during the whole period. One of the altimeters (localized at the west anchor) failed during the first deployment but was deployed again during the third deployment period, and another altimeter (localized at the north anchor) failed during the second deployment and was not deployed during the third deployment. The sampling timestep was set to $20 \mathrm{~min}$.

Net erosion fluxes (EF; integrating erosion and deposition) were calculated from the thickness of eroded sediment $\Delta h$ through time and the sediment density $\rho$ measured from sediment cores sampled during the 2003-2004 (Guillén et al., 2006) and 2004-2005 (this study) periods. The sediment density did not vary more than $10 \%$ during the study period, which was confirmed by in situ measurements from a benthic tripod deployed during 1 month on the study site (Wheatcroft, personal communication). Sediment density was thus considered as constant during the 2004-2005 period. Net EFs were calculated from

$\mathrm{EF}=\frac{\rho \Delta h}{\Delta t}$,

where $\Delta t(=20 \mathrm{~min})$ is the sampling interval of the altimetric measurements. EFs were related to the effective shear stress due to both waves and currents $\tau_{\mathrm{cws}}$, calculated from the SEDTRANS model (Li and Amos, 2001).

\subsection{Hydrodynamic modelling}

The three-dimensional model SYMPHONIE (Marsaleix et al., 2008) was used to simulate dense shelf water formation and cascading during the winter 2005. This model was previously used to study dense water cascading in the GoL (Dufau-Julliand et al., 2004; Ulses et al., 2008c) and the effect of marine storms on the exportation of shelf water during winter 2004 (Ulses et al., 2008a). The horizontal resolution was set at $1.5 \mathrm{~km}$. Vertical resolution is refined near the surface and the seafloor. This highresolution coastal simulation is nested in a $3-\mathrm{km}$ resolution regional simulation with the same model, itself initialized and forced at its lateral open boundaries by the OPA (Ocean PArallélisé) model applied at the Mediterranean scale in the frame of the MFS (Mediterranean Forecasting System) project (http://www.bo.ingv.it/mfstep/). At the sea surface, air-sea fluxes were calculated from the atmospheric parameters calculated by the limited-area numerical weather prediction model ALADIN from Météo-France at the $0.1^{\circ}$ resolution and from the SST of the ocean model through bulk formulae. The simulation was initialized in December 2004.

\section{Results}

\subsection{External forcing}

From October 2004 to November 2005, 72 windy days were recorded with mean daily wind speed $>10 \mathrm{~m} / \mathrm{s}$ (and 204 days with mean daily wind speed $>5 \mathrm{~m} / \mathrm{s}$ ). The wind direction during these windy days was SE (Marin wind) for 1 day, and NW (Tramontane) for the 71 other days (Fig. 3a). The NW wind is the main wind blowing in the south-western part of the GoL, and induces southwards alongshelf currents (Millot, 1976; Estournel et al., 2003). It is also responsible for the cooling and mixing of shelf water during winter, initiated at the coast and generates dense shelf water that flows downhill to the shelf edge and the canyons (Dufau-Julliand et al., 2004; Ulses et al., 2008c).

The Têt River is the main input of water and sediment to the coastal experimental site ( $28 \mathrm{~m}$ water depth). Between October 2004 and November 2005, the daily water discharge varied from 1.5 to $81.2 \mathrm{~m}^{3} / \mathrm{s}$ (Fig. 3b). No significant flood event occurred during this period $\left(Q=180 \mathrm{~m}^{3} / \mathrm{s}\right.$ for 2 years recurrence interval floods). The contribution of the Têt River to the coastal zone was very low compared to the previous year during which several extreme flood events occurred (Bourrin et al., 2008). No significant flood of the northern coastal rivers along the GoL coastline occurred. The Rhône River, the major input to the GoL, was characterized by low water discharges, except for the early November 2004 and April 2005 small floods. The average discharge between December 2004 and March 2005 was $1380 \mathrm{~m}^{3} / \mathrm{s}$, which was a low value compared with the mean December-March discharge $\left(1970 \mathrm{~m}^{3} / \mathrm{s}\right)$.

\subsection{Coastal measurements}

\subsubsection{Hydrology and temperature}

The water temperature at $28 \mathrm{~m}$ water depth at the coastal site showed two contrasted situations during the study period (Fig. 4a). The summer situation showed high water temperature (up to $22^{\circ} \mathrm{C}$ ) during October 2004 and from May to the end of October 2005, interrupted by periods of variable temperature during episodes of strong continental winds. The autumn and winter 2004-2005 period showed a progressive cooling of the coastal water down to $9^{\circ} \mathrm{C}$, which produced a significant increase of the water density. Hydrological observations indicated that the coastal water started to get denser than the offshore shelf water $\left(\sim 28.8 \mathrm{~kg} / \mathrm{m}^{3}\right)$ when coastal water temperature decreased below about $12.5^{\circ} \mathrm{C}$. Thus, the preconditioning phase (mixing and initial cooling of the shelf water) lasted from October to late December 2004, and the formation of dense shelf water lasted from January to early April 2005.

CTD and turbidity data collected in October 2004 and February 2005 (Figs. 5 and 6) characterized the most significant seasonal change of the hydrological conditions prevailing on the shelf, shifting from stratified conditions during summer and autumn to unstratified conditions during winter and early spring. Comparison of measured turbidity profiles and ADCP-derived turbidity profiles are shown in Figs. $5 c$ and $6 c$. While ADCP-derived estimations fitted well with optical measurements from the 

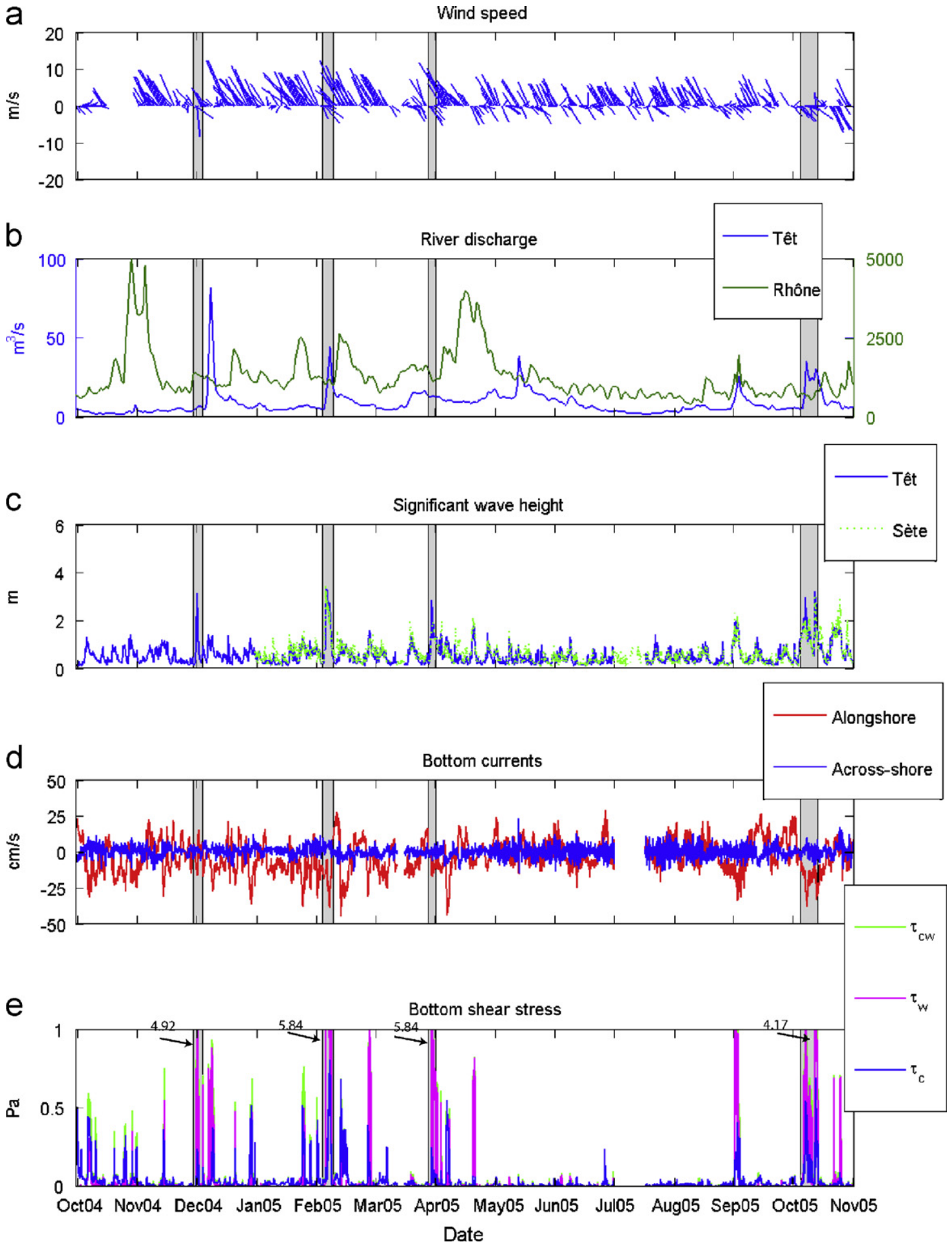

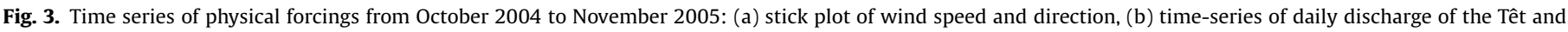

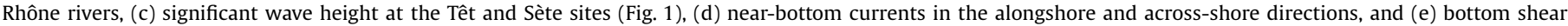

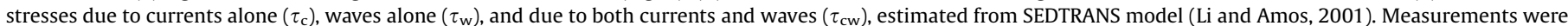

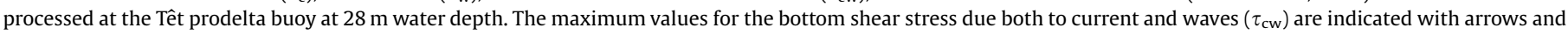
labels. Storm events are indicated with grey boxes.

surface to the last $5 \mathrm{mab}$, the comparison is not so good in the bottom layer. Extrapolation of ADCP-derived turbidity profiles in the last 2 mab overestimated the measurements by about twoorders of magnitude. SSC and fluxes are overestimated in the last 2 mab by the extrapolation made, and we choose to use the suspended-sediment fluxes estimated from the first ADCP cell measurements (2 mab). On the October 2004 CTD transect, the pycnocline bowed down and impinged the seafloor around $50-60 \mathrm{~m}$ depth, and formed a frontal zone between the warmer, fresher and lighter inner-shelf water, and colder, saltier and denser outer-shelf water (Fig. 5a). Turbidity measurements revealed the presence of a benthic nepheloid layer of several 
a

Temperature
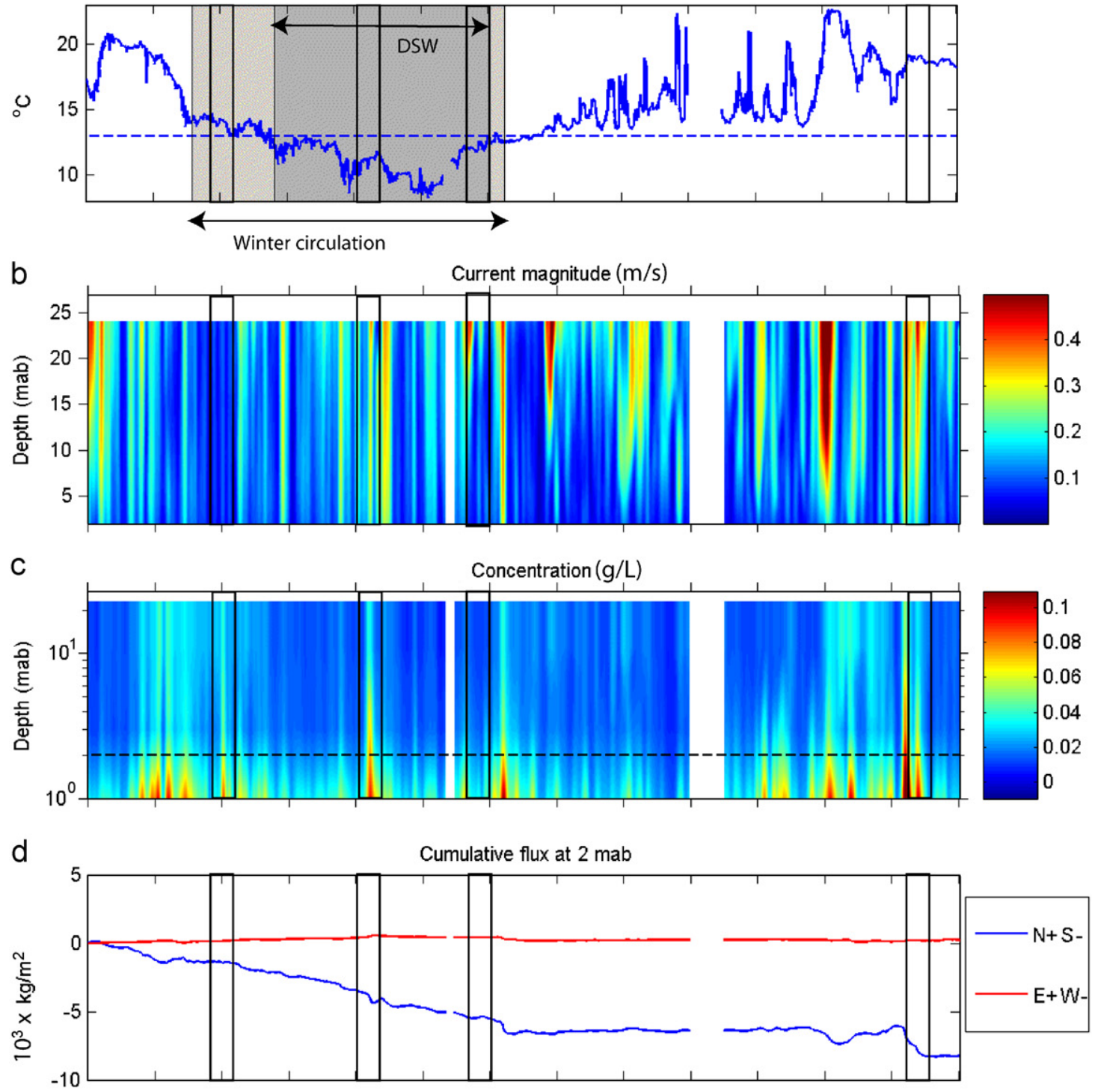

e

Bed level

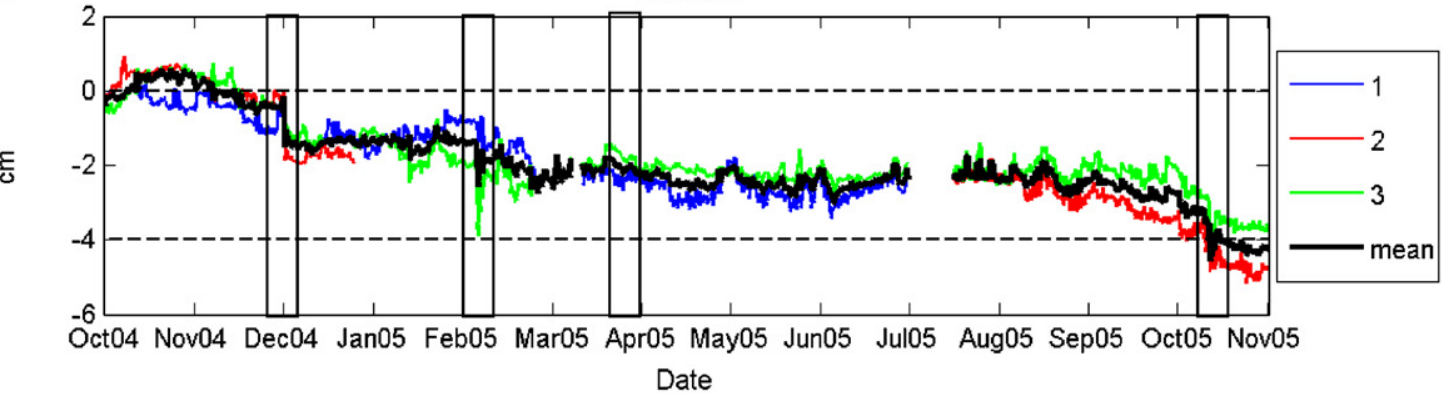

Fig. 4. (a) Time-series of temperature at 0.5 mab from October 2004 to November 2005. The dotted line is the temperature from which the water density at the inner-shelf exceeds the water density on the outer-shelf, (b) colour plot of the current magnitude in $\mathrm{m} / \mathrm{s}$, from 2 to $23 \mathrm{mab}$, (c) colour plot of the concentration in $\mathrm{g} / \mathrm{L}$, derived from acoustical backscattering intensity from 2 to $23 \mathrm{mab}$, (d) cumulative suspended-sediment horizontal fluxes measured at 2 mab, and (e) evolution of the seabed level measured at the Têt site at $28 \mathrm{~m}$ water depth by the three altimeters positioned under the buoy and mean signal (see Fig. $2 \mathrm{~b}$ for their localization; north of the buoy: blue line, west: red line, and south: green line). Storm events are indicated with boxes.

metres above the bottom all across the shelf, but a maximum turbidity area was observed just above the pycnocline between 25 and $55 \mathrm{~m}$ water depth (Fig. 5b). On February 2005 CTD transect (Fig. 6a), the water column was unstratified, with lower temperature of about $9.5-10{ }^{\circ} \mathrm{C}$ from the coast down to a water depth of about $70 \mathrm{~m}$, and warmer water about $11-12^{\circ} \mathrm{C}$ further offshore. The turbidity distribution across the shelf was rather homogeneous (Fig. 6b). 

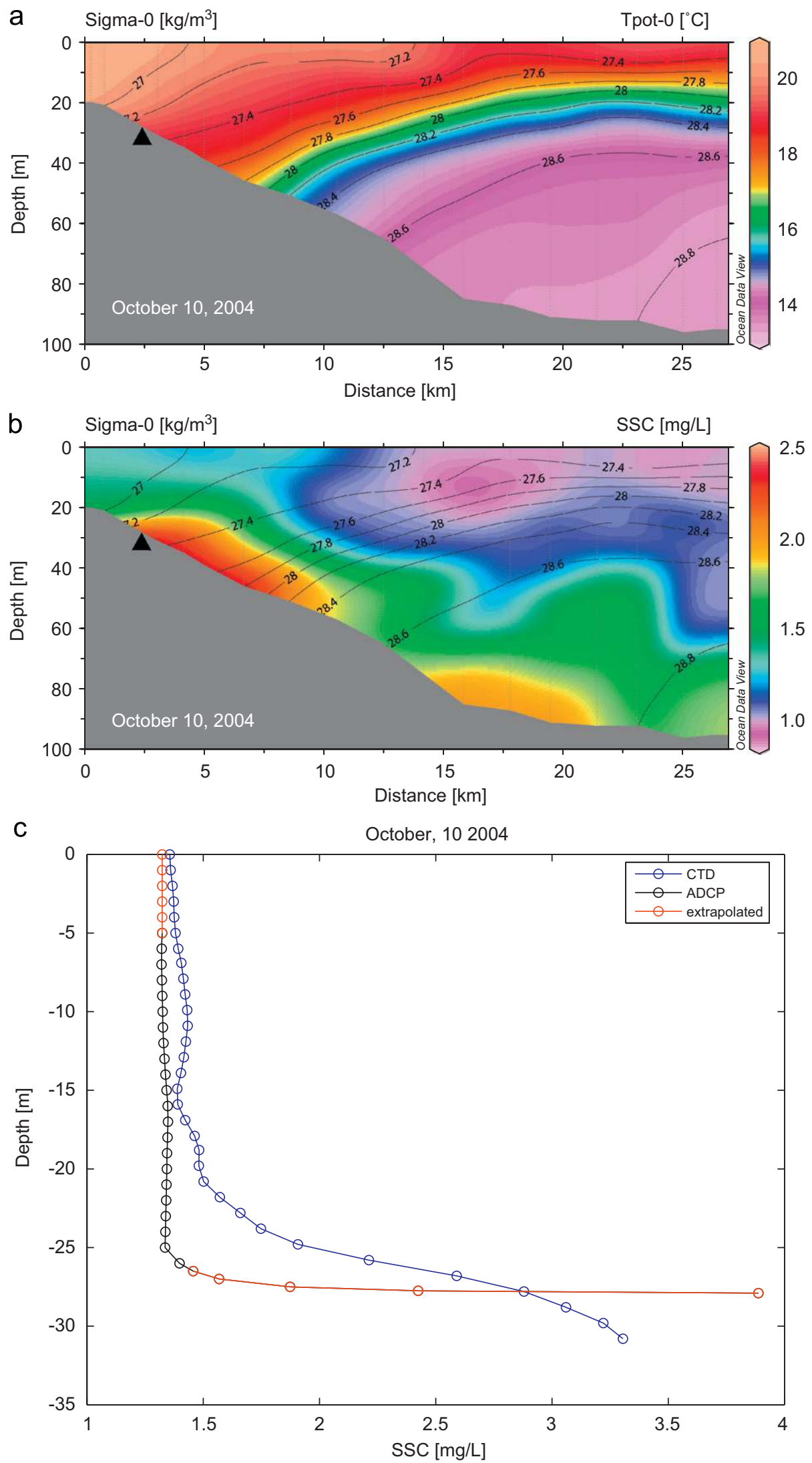

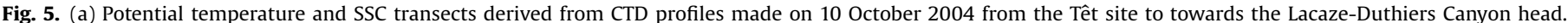

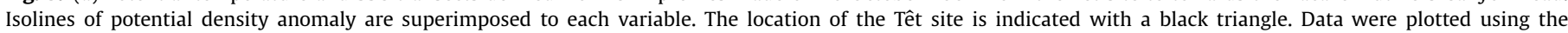
visualization program Ocean Data View (Schlitzer, 2007). (b) Comparison between SSC profile measured from CTD and SSC profile derived from ADCP measurements. 
a

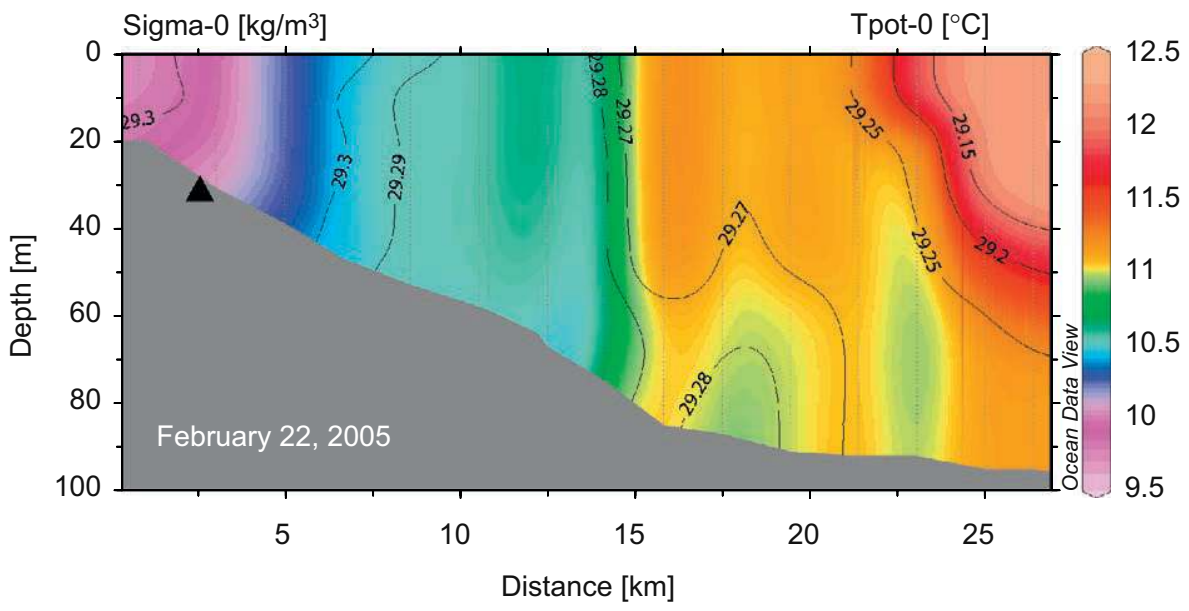

0 .5

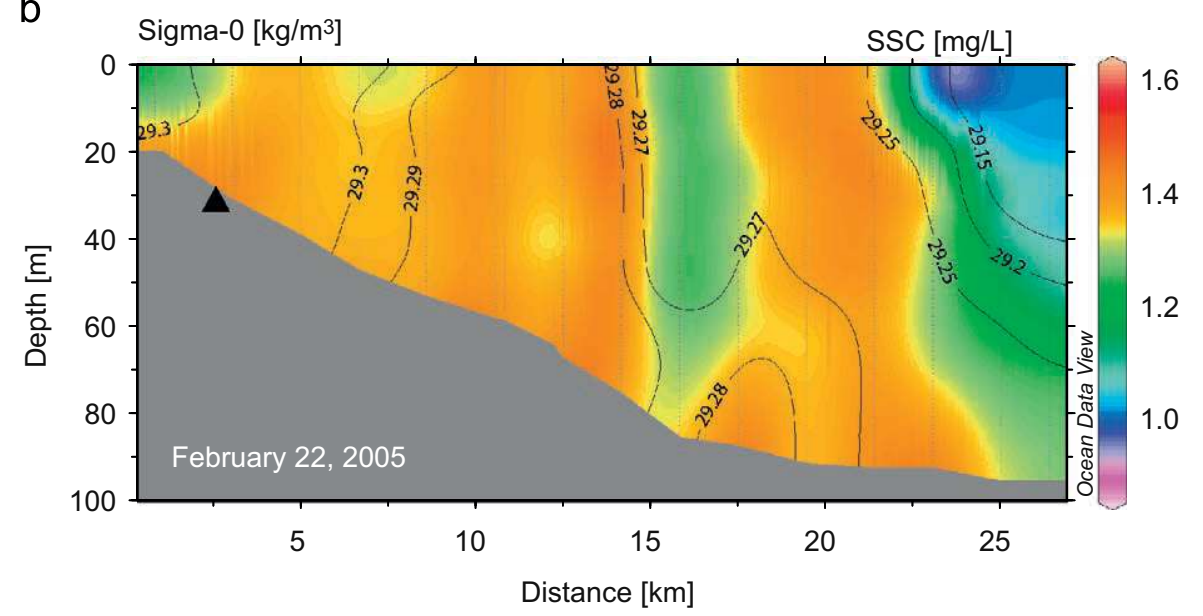

C

February, 222005

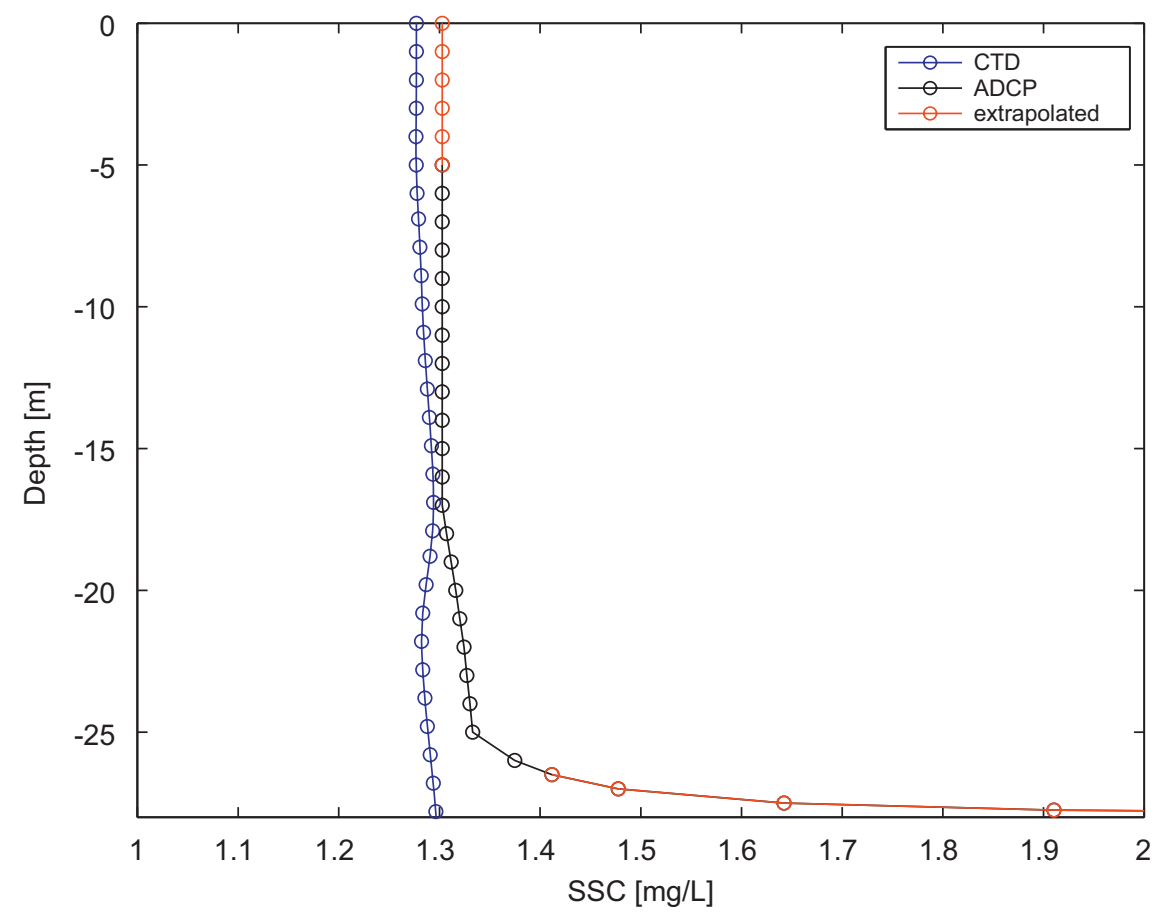

Fig. 6. (a) Potential temperature and (b) SSC transect derived from CTD profiles made on 22 February 2005 from the Têt site towards the Lacaze-Duthiers Canyon head. Isolines of potential density anomaly are superimposed. The location of the Têt site is indicated with a black triangle. Data were plotted using the visualization program Ocean Data View (Schlitzer, 2007). (c) Comparison between SSC profile measured from CTD and SSc profile derived from ADCP measurements. 
a
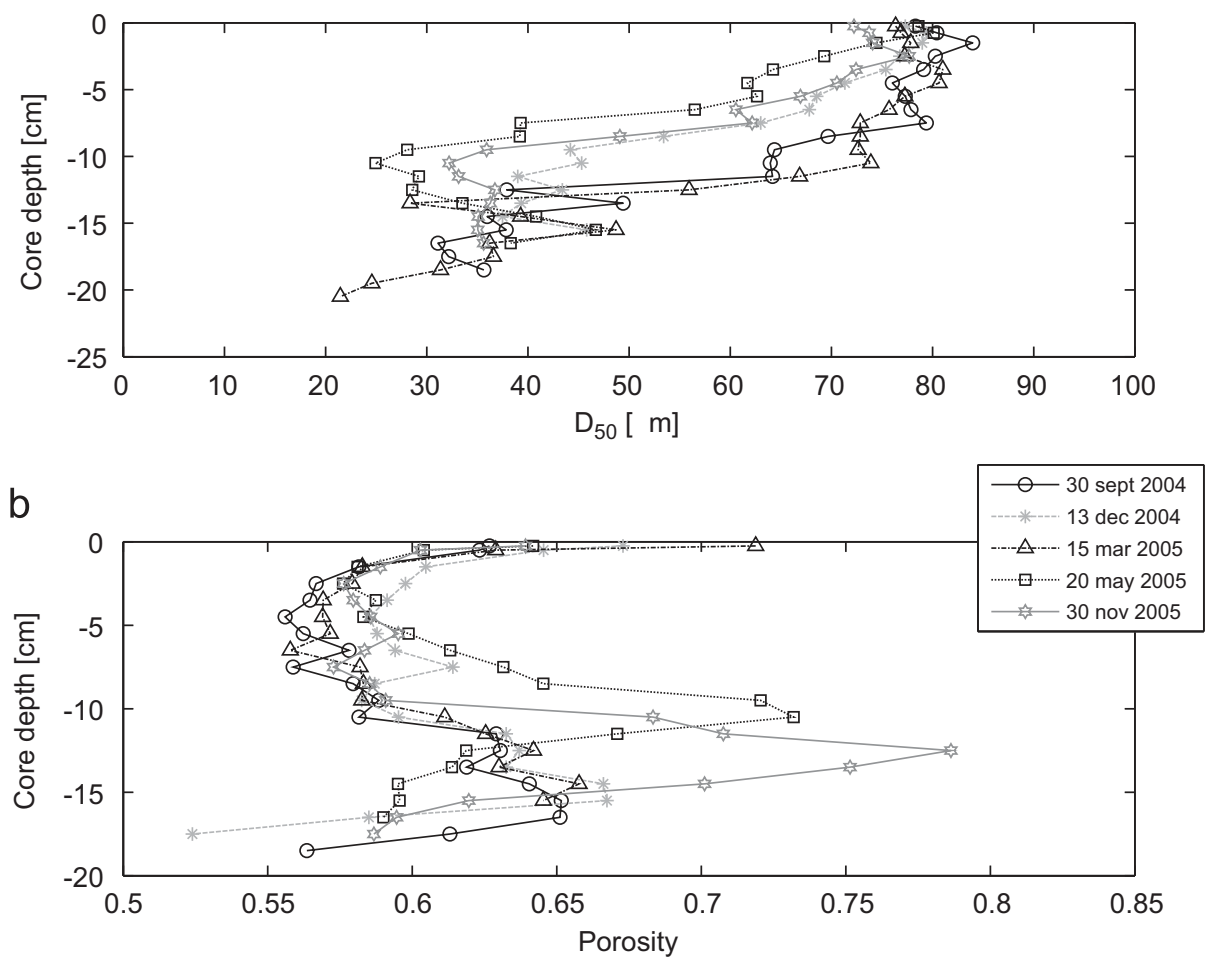

Fig. 7. (a) Median grain-size profiles and (b) porosity profiles of sediment cores sampled at the Têt site from September 2004 to November 2005.

\subsubsection{Waves and currents}

Waves are the main stirring mechanism causing bottom sediment resuspension in the Mediterranean Sea. Four storm events with significant wave height $\left(H_{\mathrm{s}}\right) \geqslant 3 \mathrm{~m}$ and period $\left(T_{\mathrm{p}}\right) \approx 9 \mathrm{~s}$ were recorded during the study period (November 2004, February 2005, April 2005, and October 2005; Fig. 3c). These moderate storm events are common in the GoL $\left(H_{\mathrm{s}}=5.5 \mathrm{~m}\right.$ for 2 years recurrence return interval storm).

Near-bottom currents ( 2 mab) measured at the coastal site (Fig. 3d) showed that the alongshore-current component predominated over the cross-shore component. Near-bottom currents were oriented mainly towards the south with a mean magnitude of 10 and $4 \mathrm{~cm} / \mathrm{s}$ in winter and summer, respectively. Bursts of southwardly near-bottom currents up to $40 \mathrm{~cm} / \mathrm{s}$ were observed during winter. From January to mid-April 2005, bottom currents were regularly larger than $20 \mathrm{~cm} / \mathrm{s}$.

The shear stress due to currents $\left(\tau_{\mathrm{c}}\right)$ exceeded the shear stress due to waves $\left(\tau_{\mathrm{w}}\right)$ for most of the monitoring period, except during the rare and brief E-SE storm events (Fig. 3 e). $\tau_{\mathrm{c}}$ exceeded the calculated critical value for sediment resuspension (corresponding to a current of $10 \mathrm{~cm} / \mathrm{s}$ for $D_{50}=80 \mu \mathrm{m}$ from Sedtrans model) for more than $10 \%$ of the time during winter.

3.2.3. Suspended-sediment concentration and cumulative fluxes, seabed level monitoring and sediment variability

ADCP-derived near-bed SSC ( $0.1 \mathrm{mab})$ at the Têt site varied from a few $\mathrm{mg} / \mathrm{L}$ to about $1.5 \mathrm{~g} / \mathrm{L}$ during high wave and current speed events (Fig. 4c). SSC rapidly decreased with increasing distance from the seabed. Maximum SSC at 1 and 10 mab reached 0.21 and $0.08 \mathrm{~g} / \mathrm{L}$, respectively, during the most energetic events. Suspended-sediment fluxes deduced at 2 mab (Fig. 4d) showed that the across-shelf component was negligible, whilst the cumulated alongshelf southward component continuously in- creases through the winter period 2004-2005. Suspendedsediment fluxes were negligible in summer and the increasing southward trend started again in October 2005 at the end of the monitoring period.

The comparison of altimetric measurements at each anchor of the buoy, show the spatial variability of the seabed level at the measurement site (Fig. 4e). Differences between signals measured by the three altimeters are observed during the whole period of measurement and particularly during storm events, but the trend of each seabed level measurement show the same pattern. The mean of the three measurements is then used to describe the change of the seabed level at the Têt site. This signal showed a net sediment erosion of about $4-5 \mathrm{~cm}$ between October 2004 and November 2005 (Fig. 4e). After a low-sediment accretion period in October 2004, sediment erosion of about $2 \mathrm{~cm}$ was observed from November 2004 to February 2005. The springsummer period (March-August 2005) was characterized by a relative stability of the bed level. A second period of sediment erosion of about $2 \mathrm{~cm}$ was then observed at the end of the monitoring period (September-November 2005). The largest variations occurred during the mild storms (with higher wave energy) in November 2004, February and October 2005. Net sediment erosion of about $1 \mathrm{~cm}$ was measured after these events except in February 2005 when no significant change was observed.

Surface sediment median grain-size varied between 72 and $82 \mu \mathrm{m}$ from 30 September 2004 to 30 November 2005 (Fig. 7a). Small variations were observed in the top $5 \mathrm{~cm}$ during that period and reflected the spatial variability of the sediment properties in this area. The porosity of the surface sediment varied between 0.62 and 0.72 during the same period (Fig. 7b). No significant change was observed during the study period. Abrupt changes were observed at $10-15 \mathrm{~cm}$ in the sediment cores of 20 May and 30 November 2005 due to bioturbation. 


\subsection{Modelling of dense water flow on the shelf}

\subsubsection{February-March average flow}

The near-bottom temperature and flow averaged during the main dense shelf water formation (February-March 2005) provide a general view of the distribution of the dense shelf water core (Fig. 8). During the February-March period, the coldest $\left(\leqslant 10^{\circ} \mathrm{C}\right)$ and densest near-bottom water was contained on the inner and mid-shelf (Fig. 8a). The averaged near-bottom current (Fig. 8b) was cyclonic and oriented along isobaths over most of the midshelf, and the western inner-shelf (below $43^{\circ} \mathrm{N}$ ). An acceleration of the along-shelf flow was observed in the southwestern part of the gulf, due to the narrowing of the shelf. The Cap de Creus area appears as the main outlet for this alongshore transport.

The average current intensity through the cross-shelf transect joining the Têt prodelta to the Lacaze-Duthiers Canyon head is about $8-10 \mathrm{~cm} / \mathrm{s}$, but reached maximum daily average speed of $25 \mathrm{~cm} / \mathrm{s}$ (data not shown).

\subsubsection{Dense water plume extent}

The sequence of temperature and currents shown in Fig. 9 illustrates the changes of the cross-shelf extent of the dense shelf water core during a 2-week period (15 February-1 March 2005) encompassing the hydrological observations (22 February) depicted in Fig. 6.

The cold and dry NW wind (Tramontane) became strong from 13 February. The newly formed dense water $\left(T<10^{\circ} \mathrm{C}\right)$ formed a southward flowing core that remained stuck at the coast and extended down to $40 \mathrm{~m}$ isobath on 19 February. The northwards wind-driven counter-current that took place on the outer-shelf originated from the intrusion of slope waters near the LacazeDuthiers Canyon. The wind weakened durably from 22 February

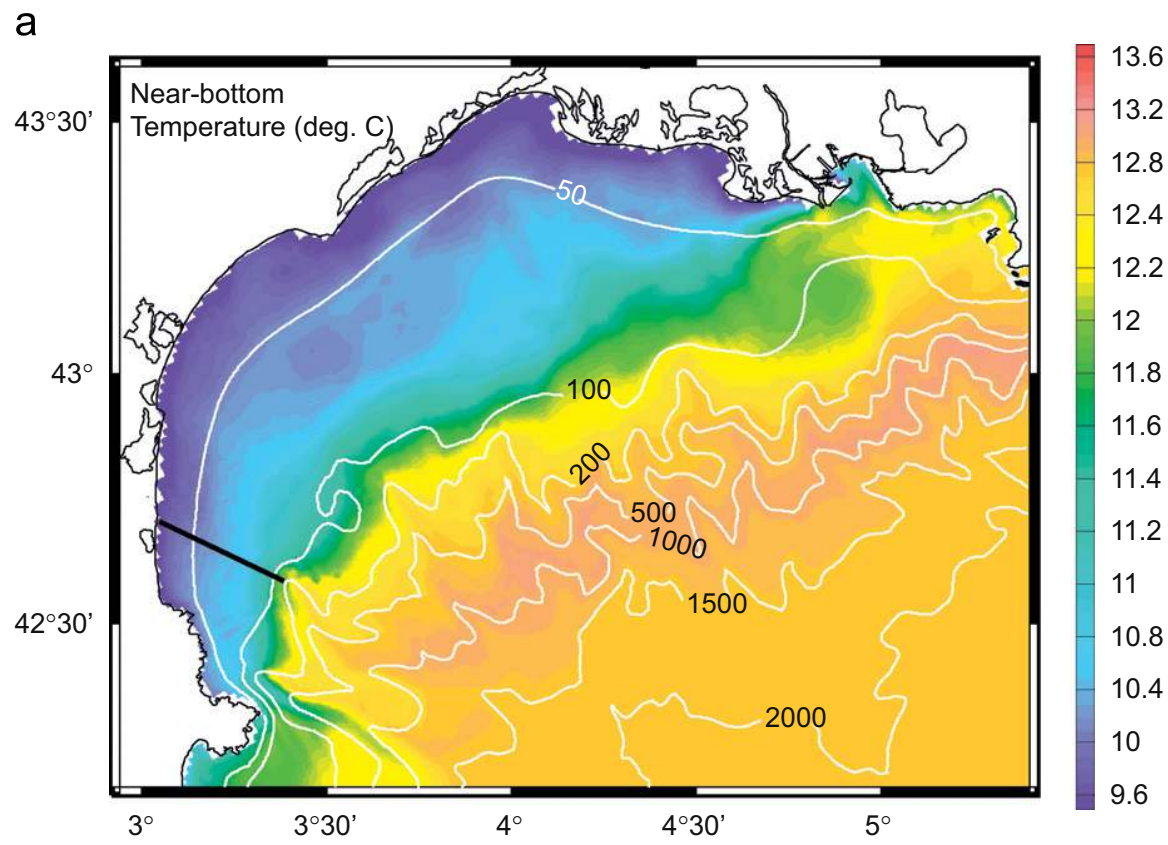

b

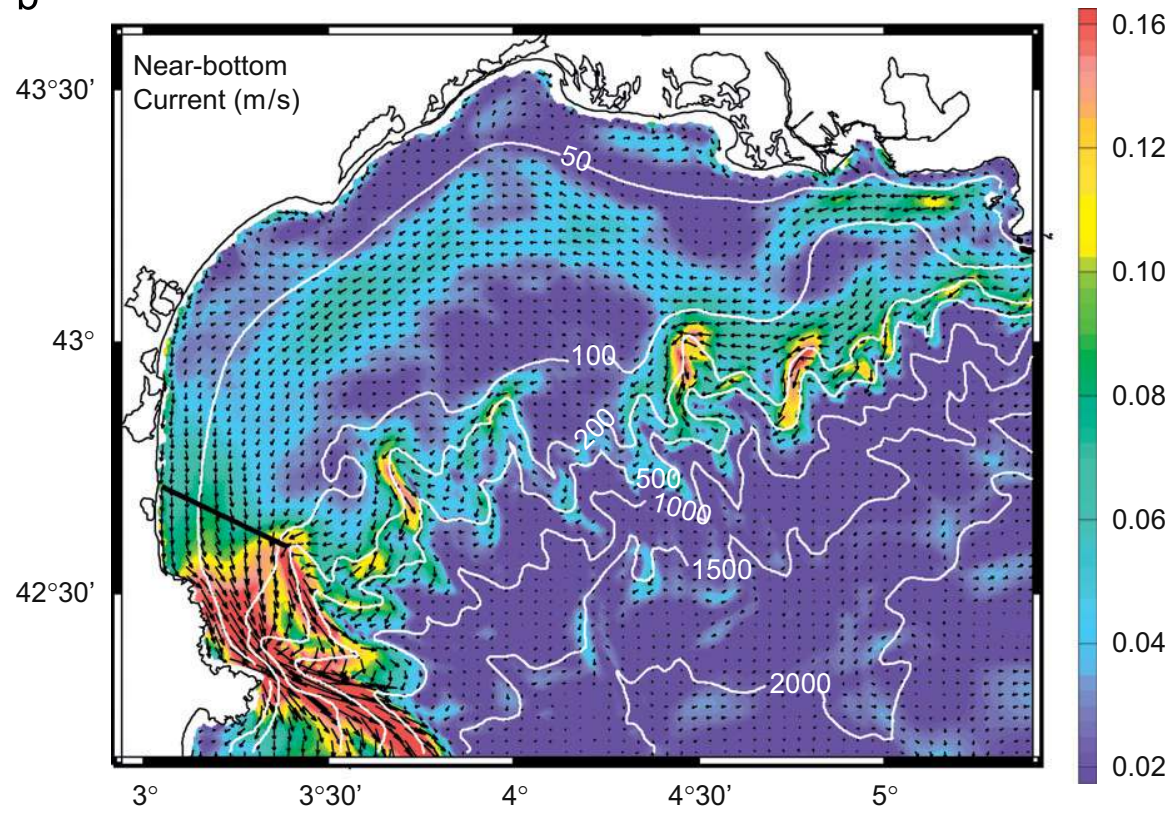

Fig. 8. Modelled average near-bottom (10 mab) temperature (a) and current (b) for the February-March 2005 period over the Gulf of Lions' shelf and slope (Symphonie model). The coloured pattern superimposed to the arrows indicates the speed of the average currents. 

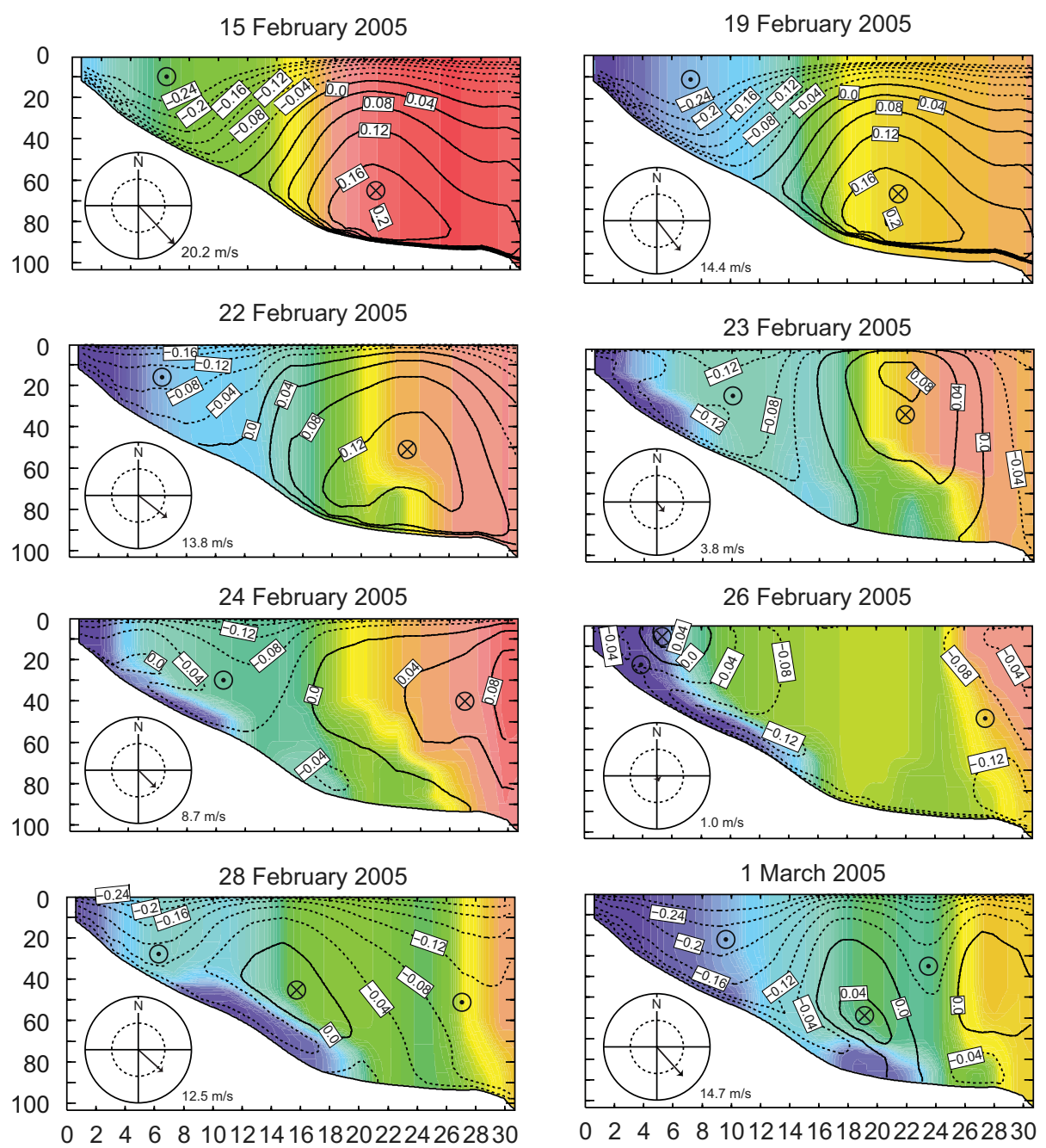

Temperature $\left({ }^{\circ} \mathrm{C}\right)$

$\begin{array}{llllllllllllllll}9.2 & 9.6 & 10 & 10.2 & 10.4 & 10.6 & 10.8 & 11.0 & 11.2 & 11.4 & 11.6 & 11.8 & 12.2 & 12.6\end{array}$

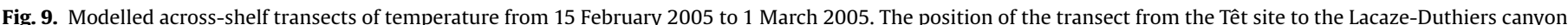

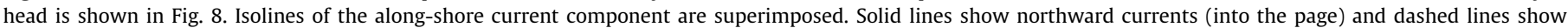

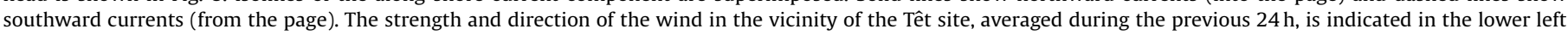
corner of each panel.

to 26 February, and starting on 23 February, a bottom plume of dense water spread cross-shelf to reach a depth of $70 \mathrm{~m}$ on 26 February. The wind strengthened again on 27 February. The dense water formed in shallow water remained again confined at the coast, while the plume that previously reached the mid-shelf continued to flow downhill and eventually formed a distinct filament on the flat outer-shelf around $80 \mathrm{~m}$ deep. The velocity of the cross-shore flow of the dense shelf water core was about $4 \mathrm{~cm} / \mathrm{s}$.

These results show that while the inner-shelf of the southwestern gulf is continuously affected by the dense shelf water flow, the mid- and outer-shelves are affected only intermittently.

\section{Discussion}

\subsection{Seasonal and interannual variability of shelf sediment erosion}

Seabed level variations monitored on the Têt prodelta show a strong seasonality. Seabed erosion only occurred during autumn and winter. Comparison with the hydrodynamical forcing (Fig. 4) reveals two different regimes associated to waves and currents (E-SE storms), or to currents alone (wind-induced coastal currents and dense shelf water flow). Net erosion can only occur if there is flux divergence. Modelling results for E-SE storms (Ulses et al., 2008b) and for wind-induced coastal current/dense shelf water flow (this study, Fig. 8) shows that flow divergence takes place at the Têt site because of the downstream flow acceleration due to the narrowing of the southern end of the shelf.

Whereas storm events induced brief $(\sim 1 \mathrm{~d})$ and large $(\sim 1 \mathrm{~cm})$ changes of the seabed level, the strong and prolonged ( $\sim 2$ months: January-February 2005) alongshore wind-induced coastal current enhanced a slow but continuous erosion $(\sim 2 \mathrm{~cm})$ of the seabed. The relative stability observed in summer suggests that there is no significant erosional trend-because of the absence of storm events and the weakness of the near-bottom currents-and therefore no significant deposition, deriving from river input or settling of marine biological material. During the 2004-2005 autumn and winter periods, the wind-induced coastal current appears thus as the predominant erosion mechanism on 
the inner-shelf, and we supposed that the dense shelf water flow promoted the transport of eroded material toward the shelf edge. Dense shelf water-flow speed can be estimated from the Nof speed formulation (Nof, 1983; Shapiro and Hill, 1997):

$V_{\text {Nof }}=\frac{g^{\prime} s}{f}$,

where the Nof speed is the speed with which the dense water plume would have propagated along the contours of constant depth if there had been no friction (Nof, 1983); $g^{\prime}$ is the reduced gravity acceleration and $s$ the shelf slope $(s=\tan \theta)$. The estimation of the dense shelf water flow from measurements made in February 2005 gives a value of $\sim 10 \mathrm{~cm} / \mathrm{s}$ which is two to four times lower than measured currents during that period. Thus, the wind-induced coastal current is the main mechanism causing sediment resuspension in the Têt inner-shelf but associated dense shelf water flow enhanced the advection of suspended material towards the exit of the Gulf of Lion during the winter 2004-2005.

Interestingly, during the previous 2003-2004 autumn and winter periods, at the same coastal site, Guillén et al. (2006) showed that the sediment erosion by storms largely exceeded the sediment erosion by currents alone. Large storms caused sediment erosion of up to $5 \mathrm{~cm}$, generally followed by a deposition of similar amplitude (Fig. 10). The net erosion of the seabed during both years varied between $\sim 1 \mathrm{~cm}$ in 2003-2004 and $4 \mathrm{~cm}$ in 2004-2005 (Fig. 10).

It is worthy to note that the 2003-2004 and 2004-2005 periods are distinguished by unusually energetic hydro-climatic conditions. The 2003-2004 autumn and winter periods were characterized by two large $\left(H_{\mathrm{s}}>7 \mathrm{~m}\right)$ and three moderate $\left(H_{\mathrm{s}}>3 \mathrm{~m}\right)$ storms as well as several extreme floods of the Rhône and of the smaller rivers. Mild dense shelf water formation took place during that period (Ulses et al., 2008a). The 2004-2005 autumn and winter periods were characterized by very intense dense shelf water formation and only two moderate storms. The typical return period of extreme dense shelf water formation (Béthoux et al., 2002; Canals et al., 2006) and of extreme storm $\left(H_{\mathrm{s}}>7 \mathrm{~m}\right)$ events in the GoL is between 5 and 10 years. Extreme flood events such as the December 2003 Rhône flood event has an interval return period of about 100 years. Thus, the 2003-2004 and 2004-2005 experiments allowed us to assess the impact of extreme events on the seabed level. The centimetric annual erosion induced by these extreme events is likely to be the main factor that restrict the secular sedimentation rate, estimated in the Têt inner-shelf to $\sim 0.1 \mathrm{~cm} /$ year (Bourrin et al., 2007), despite the local and upstream rivers inputs. This fact also suggests that accretion should dominate during less energetic periods to balance the erosion observed during these two consecutive years.

\subsection{Net erosion fluxes, suspended-sediment concentration and transport}

Altimetric measurements allowed us to estimate the $\mathrm{EF}$ for the mixed sediment at the coastal station $\left(D_{50}=70-80 \mu \mathrm{m}\right.$ and porosity $=60-70 \%$ in the $0-2 \mathrm{~cm}$ layer) for a large range of bottom shear stress (0-9 Pa). The effective bottom shear stress (total bottom shear stress due to both currents and waves) range was much higher in 2003-2004 (0-9 Pa) than in 2004-2005 (0-1 Pa). Considering the whole dataset (Fig. 11a), one observes a rapid increase of EF up to $1.2 \mathrm{~g} / \mathrm{m}^{2} / \mathrm{s}$ with increasing $\tau_{\mathrm{cws}}$ up to $2 \mathrm{~Pa}$. Beyond that limit, the increase of EF with bottom shear stress is lower and reached $1.8 \mathrm{~g} / \mathrm{m}^{2} / \mathrm{s}$ for $\tau_{\mathrm{cws}}=9 \mathrm{~Pa}$. Bed armouring, which limits the amount of fine-grained sediment available for resuspension, could be one reason to explain the lower increase of EF at high shear stress (Wiberg et al., 1994). Ferré et al. (2005) inferred from observations and numerical simulations on a shallower and sandier site close to the present study site, the influence of the bed armouring that limits, during a storm event, the resuspension of fine-grained sediment after the winnowing of the superficial sediment layer.
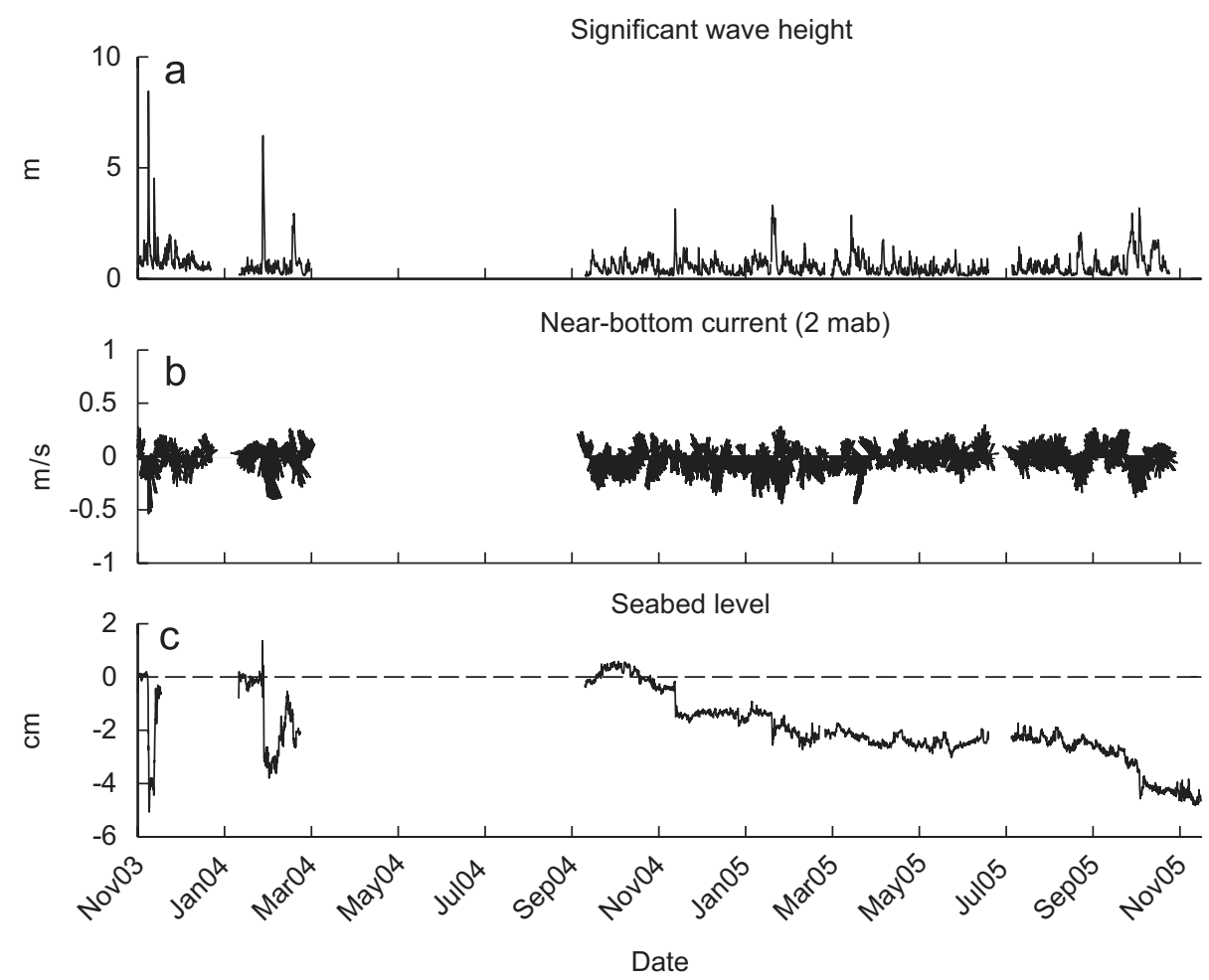

Fig. 10. (a) Significant wave height, (b) near-bottom currents, and (c) seabed level measured at the Têt site during monitoring periods $2003-2004$ and $2004-2005$. 


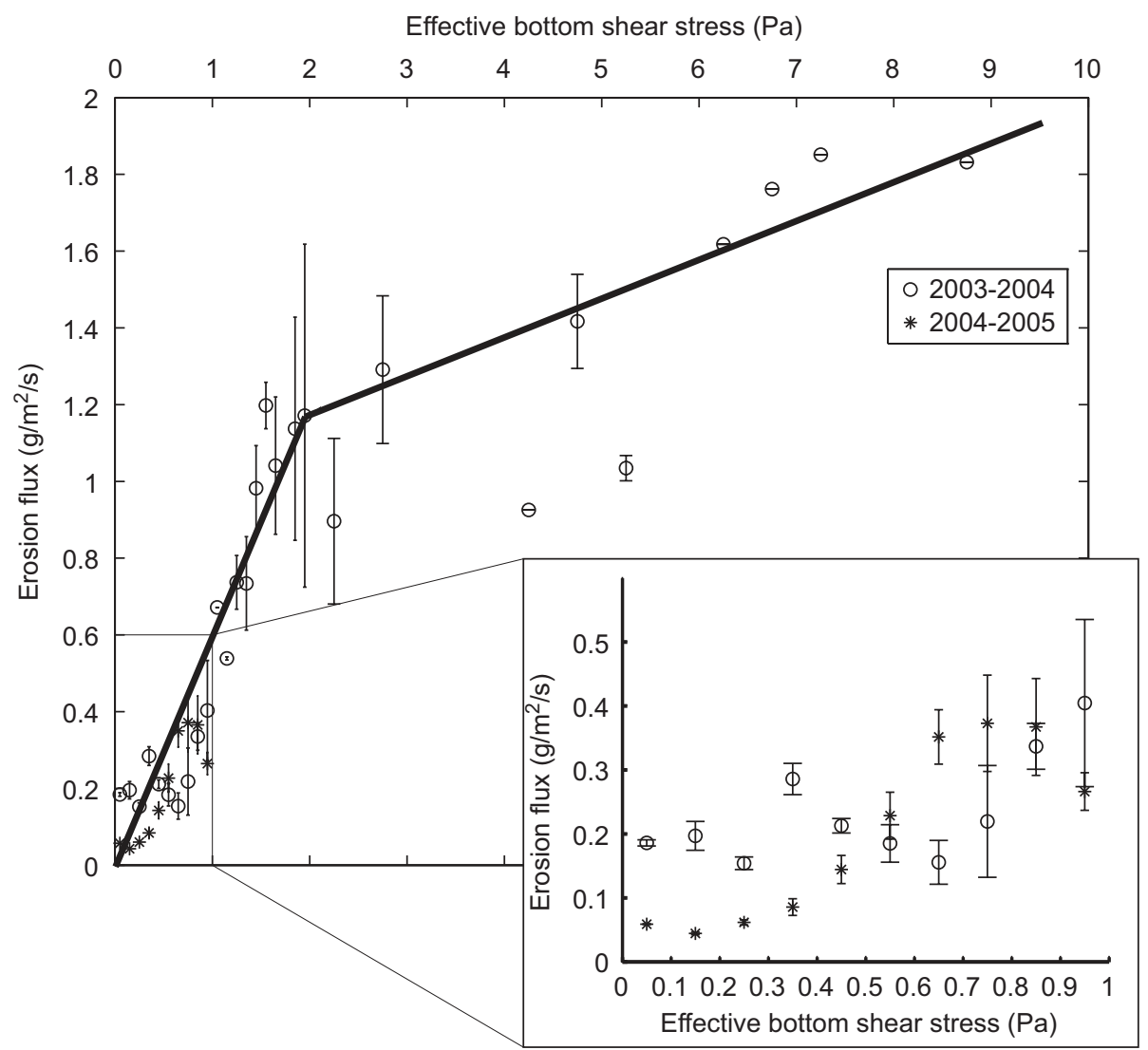

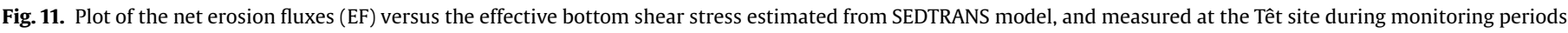
2003-2004 and 2004-2005: (a) 0-10 Pa range and (b) zoom on 0-1 Pa range.

Net EFs for the 2003-2004 period are three to four times higher than the 2004-2005 period at low-bottom shear stress $\left(\tau_{\text {cws }}<0.5 \mathrm{~Pa}\right.$, Fig. $\left.11 \mathrm{~b}\right)$, but are comparable for higher shear stress (up to 1 Pa, Fig. 11a). This different behaviour at low shear stress could result from the change in the surface sediment porosity, which significantly varied during the 2003-2004 period as a result of floods and storms (Bourrin et al., 2007) but were rather constant during the 2004-2005 period (Fig. 7b). Finegrained sediment deposits following flood events and reworking of the sediment by storms temporarily increase the surface layer porosity (Bourrin et al, 2007) and thus enhance the subsequent resuspension at low shear stress. This difference vanishes at higher shear stress as the thickness of the eroded layer increases and reaches level where sediment porosity is more constant (Fig. 7b).

The two major resuspension regimes (moderate storms or currents alone) observed during the 2004-2005 experiment have a different response in terms of SSC in the water column. While significant increases of SSC are observed within the last 10 mab during storm-induced resuspension, no significant increases of SSC are observed during the prolonged erosion phase induced by dense shelf water flow (Fig. 4c). However, the impact of the latter mechanism is well evidenced on the sediment transport (Fig. 4d and e). Net erosion and alongshore sediment transports during the winter 2004-2005 show similar trends during the whole measurement period. Storm-induced resuspension and subsequent SSC increase do not affect significantly the seasonal trend of the alongshore transport. During that winter, resuspension and transport associated with wind-induced coastal current and dense shelf water flow dominates the sediment dynamics on the Têt inner-shelf. Nevertheless, in view of the comparable sediment thickness (few $\mathrm{cm}$ ) eroded by both type of events, it is likely that the discrepancy between storm-induced and dense shelf waterinduced sediment transport results from the area affected by these events upstream of the Têt shelf. Storms impact on the entire inner-shelf of the GoL (Ulses et al., 2008b), and the cyclonic alongshore current-which incorporates the resuspended sediment all along its pathway-yields a large transport on the Têt shelf. Conversely, the wind-induced coastal current and dense shelf water flow on the inner-shelf impacts a smaller region upstream of the Têt shelf, and thus limits the downstream increase of suspended-sediment transport.

Measurements of temperature, current, and sediment transport made at the Têt site are well correlated to measurements made in the head of the south-western Lacaze-Duthiers and Cap de Creus Canyons (Ogston et al., 2008; Puig et al., 2008), confirming the potential of wind-induced coastal current and associated dense shelf water flow to resuspend and carry sediment. Ogston et al. (2008) show that dense shelf water flows were more episodic and weaker in the Lacaze-Duthiers Canyon than in the Cap de Creus Canyon, emphasizing the preferential pathway of dense shelf water flow toward the southern end of the GoL, and Puig et al. (2008) show the impact of dense shelf water flows on the seabed erosion deeper in the Cap de Creus Canyon.

\section{Conclusions}

This paper investigated the impact of winter wind-driven circulation and cold dense shelf water flows on the sediment dynamics on the Têt prodelta in the south-western GoL's shelf. 
The most important findings of this work are the following:

- Sediment erosion of several centimetres occurred on the Têt prodelta during the winter period 2004-2005 due to the strong wind-driven current flowing southwards along the coast. During the unusual cold and dry winter 2004-2005 that only occurred three times in the last decades, this current was transformed in a gravity flow due to the large cooling and subsequent increase of its density. Conversely, sediment erosion measured at the same site during the previous winter 2003-2004, an unusual winter with extreme storms and floods, was nearly balanced by river inputs. During these two consecutive winters, the Têt prodelta underwent a net erosion of $\sim 4 \mathrm{~cm}$ that is much higher and opposite to the local secular apparent sedimentation rate $(\sim 0.1 \mathrm{~cm} /$ year $)$.

- Net EFs were measured in situ at high and very high effective shear stresses compared to those measured in laboratory. Net EFs for the lower shear stresses (0-2 Pa) clearly appear to depend on the sediment history, whereas they are more constant at higher shear stresses. The largest net EFs, which are linked to the extreme storm events, are possibly limited by bed armouring.

- Wind-induced coastal current and severe dense shelf water flow are important winter mechanisms for sediment erosion and southwards alongshore transport. The extent of the region impacted by dense shelf water flows is variable, depending on the wind-driven circulation on the shelf. The wind-induced coastal current and associated dense shelf water flow continuously eroded the inner-shelf but impacted more episodically the mid- and outer-shelf. Dense shelf water-flow measurements on the shelf are well correlated to contemporary measurements made in the south-westernmost canyons of the Gulf.

\section{Acknowledgements}

The authors acknowledge the support of the SysCoLag program from the Regional Council of Languedoc-Roussillon and the ECfunded program EuroStrataform (EVK3-CT-2002-00079, EU Fifth Framework Program: Energy, Environment and Sustainable Development). They warmly thank the captain and crews of the R/V Téthys II, Oceanus and Endeavor. Special thank is addressed to the technical staff of CEFREM, Gilles Saragoni and Jacques Carbonne.

\section{References}

Aloïsi, J.C., 1986. Sur un modèle de sédimentation deltaïque. Contribution à l'étude des marges passives. Ph.D. Thesis, University of Perpignan, 162pp.

Aloïsi, J.C., Got, H., Monaco, A., 1973. Carte géologique du précontinent languedocien au 1/250000ième. International Institute for Aerial Survey and Earth Sciences (I.T.C.), The Netherlands.

Bassoullet, P., Le Hir, P., Gouleau, D., Robert, S., 2000. Sediment transport over an intertidal mudflat: field investigations and estimation of fluxes within the "Baie de Marennes-Oleron" (France). Continental Shelf Research 20 (12/13), 1635-1653.

Bergamasco, A., Oguz, T., Malanotte-Rizzoli, P., 1999. Modelling dense water mass formation and winter circulation in the northern and central Adriatic Sea. Journal of Marine Systems 20 (1-4), 279-300.

Berné, S., Satra, C., Aloïsi, J.C., Baztan, J., Dennielou, B., Droz, L., Dos Reis, A.T., Lofi, J., Méar, Y., Rabineau, M., 2002. Carte morphobathymétrique du Golfe du Lion, notice explicative. Ifremer, Brest.

Béthoux, J.P., Durieu de Madron, X., Nyffeler, F., Tailliez, D., 2002. Deep water in the western Mediterranean: peculiar 1999 and 2000 characteristics, shelf formation hypothesis, variability since 1970 and geochemical inferences. Journal of Marine Systems 33-34, 117-131.

Bourrin, F., Monaco, A., Aloisi, J.-C., Sanchez-Cabeza, J.-A., Lofi, J., Heussner, S., de Madron, X.D., Jeanty, G., Buscail, R., Saragoni, G., 2007. Last millennia sedimentary record on a micro-tidal, low-accumulation prodelta (Tet NW Mediterranean). Marine Geology 243 (1-4), 77-96.
Bourrin, F., Friend, P.L., Amos, C.L., Thompson, C.E.L., Manca, E., Durrieu DeMadron X., Ulses, C., 2008. An oceanic flood in a microtidal, storm dominated basin: the Têt, Gulf of Lions (NW Mediterranean, France). Continental Shelf Research, this issue, doi:10.1016/j.csr.2008.06.006.

Canals, M., Puig, P., de Madron, X.D., Heussner, S., Palanques, A., Fabres, J., 2006 Flushing submarine canyons. Nature 444 (7117), 354-357.

Curran, K.J., Hill, P.S., Milligan, T.G., Mikkelsen, O.A., Law, B.A., Durrieu de Madron, X., Bourrin, F., 2007. Settling velocity, effective density, and mass composition of suspended sediment in a coastal bottom boundary layer, Gulf of Lions, France. Continental Shelf Research 27, 1408-1421.

Drake, D.E., 1976. Suspended sediment transport and mud deposition on continental shelves. In: Stanley, D.J., Swift, D.J.P. (Eds.), Marine Sediment Transport and Environmental Management. Wiley-Interscience Publication, p. 602.

Dufau-Julliand, C., Marsaleix, P., Petrenko, A., Dekeyser, I., 2004. 3D Modeling of the Gulf of Lion's hydrodynamics (NW Med.) during January 1999 (MOOGLI3 Experiment) and late winter 1999: Western Mediterranean Intermediate Water (WIW)'s formation and its cascading over the shelf break. Journal of Geophysical Research 109 (C11).

Durrieu de Madron, X., Panouse, M., 1996. Transport de matière en suspension sur le plateau continental du Golfe du Lion-Situation estivale et hivernale. Comptes Rendus de l'Académie des Sciences, Série IIa, Paris 322, 1061-1070.

Estournel, C., Durrieu de Madron, X., Marsaleix, P., Auclair, F., Julliand, C., Vehil, R., 2003. Observation and modeling of the winter coastal oceanic circulation in the Gulf of Lion under wind conditions influenced by the continental orography (FETCH experiment). Journal of Geophysical Research 108 (C3), 8059.

Estournel, C., Zervakis, V., Marsaleix, P., Papadopoulos, A., Auclair, F., Perivoliotis, L., Tragou, E., 2005. Dense water formation and cascading in the Gulf of Thermaikos (North Aegean), from observations and modelling. Continental Shelf Research 25 (19/20), 2366-2386.

Ferré, B., Guizien, K., Durrieu de Madron, X., Palanques, A., Guillén, J., Grémare, A., 2005. Fine-grained sediment dynamics during a strong storm event in the inner-shelf of the Gulf of Lion (NW Mediterranean). Continental Shelf Research $25,2410-2427$.

Guillén, J., Bourrin, F., Palanques, A., Durrieu de Madron, X., Puig, P., Buscail, R., 2006. Sediment dynamics during wet and dry storm events on the Tet inner shelf (SW Gulf of Lions). Marine Geology 234 (1-4), 129-142.

Heussner, S., Durrieu de Madron, X., Calafat, A., Canals, M., Carbonne, J., Delsaut, N., Saragoni, G., 2006. Spatial and temporal variability of downward particle fluxes on a continental slope: lessons from an 8-yr experiment in the Gulf of Lions (NW Mediterranean). Marine Geology 234, 63-92.

Ivanov, V.V., Shapiro, G.I., Huthnance, J.M., Aleynik, D.L., Golovin, P.N., 2004. Cascades of dense water around the world ocean. Progress in Oceanography 60, 47-98.

Jestin, H., Bassoullet, P., Le Hir, P., L’Yavanc, J., Degres, Y., 1998. Development of ALTUS, a high frequency acoustic submersible recording altimeter to accurately monitor bed elevation and quantify deposition or erosion of sediments. In: Proceedings of the Oceans'98-IEEC/OES Conference, Nice (France), pp. 189-194.

Land, J.M., Bray, R.N., 2000. Acoustic measurement of suspended solids for monitoring of dredging and dredged material disposal. Journal of Dredging Engineering 2 (3), 1-17.

Lapouyade, A., Durrieu de Madron, X., 2001. Seasonal variability of the advective transport of suspended particulate matter and organic carbon in the Gulf of Lions (NW Mediterranean). Oceanologica Acta 24, 295-312.

Li, M.Z., Amos, C.L., 2001. SEDTRANS96: the upgraded and better calibrated sediment-transport model for continental shelves. Computers and Geosciences 27, 619-645.

Marsaleix, P., Auclair, F., Floor, J.W., Herrmann, M.J., Estournel, C., Pairaud, I., Ulses C., 2008. Energy conservation issues in sigma-coordinate free-surface ocean models. Ocean Modelling 20 (1), 60-89.

McCave, I.N., 1972. Transport and escape of fine-grained sediment from shelf areas. In: Shelf Sediment Transport: Process and Pattern, Van Nostrand Reinhold New York, pp. 225-248.

Milliman, J.D., Syvitski, J.P.M., 1992. Geomorphic/tectonic control of sediment discharge to the ocean: the importance of small mountainous rivers. Journal of Geology 100 (5), 525-544.

Millot, C., 1976. Specific features of the sea-shore circulation near Cap Leucate Mémoires Société Royale des Sciences de Liège, 6e série (tome X), 227-245.

Nof, D., 1983. The translation of isolated cold eddies on a sloping bottom. Deep Sea Research Part A. Oceanographic Research Papers 30 (2), 171-182.

Ogston, A., Drexler, T.M., Puig, P., 2008. Sediment delivery, resuspension, and transport in two contrasting canyon environments in the southwest Gulf of Lions. Continental Shelf Research, this issue, doi:10.1016/j.csr.2008.02.012.

Palanques, A., Durrieu de Madron, X., Puig, P., Fabres, J., Guillen, J., Calafat, A. Canals, M., Heussner, S., Bonnin, J., 2006. Suspended sediment fluxes and transport processes in the Gulf of Lions submarine canyons. The role of storms and dense water cascading. Marine Geology 234 (1-4), 43-61.

Puig, P., Palanques, A., Orange, D., Canals, M., 2008. Dense shelf water cascading and furrows formation in the Cap de Creus canyon, northwestern Mediterranean margin. Continental Shelf Research, this issue, doi:10.1016/ j.csr.2008.05.002

RD Instruments, 1996. Acoustic Doppler Current Profilers-Principles of Operation: A Practical Primer, RD Instruments, San Diego, CA, USA.

RD Instruments, 2001. Waves User's Guide. 
Rouse, H., 1937. Modern conceptions of the mechanics of fluid turbulence. Transactions of the American Society of Civil Engineering 102 (463-554).

Schlitzer, R., 2007. Ocean Data View. Available from:〈http://odv.awi.de〉.

Shapiro, G.I., Hill, A.E., 1997. Dynamics of dense water cascades at the shelf edge Journal of Physical Oceanography 27 (11), 2381-2394.

Ulses, C., Estournel, C., Bonnin, J., Durrieu de Madron, X., Marsaleix, P., 2008a. Impact of storms and dense water cascading on shelf-slope exchanges in the Gulf of Lion (NW Mediterranean). Journal of Geophysical Research 113 C02010.

Ulses, C., Estournel, C., Durrieu de Madron, X., Palanques, A., 2008b. Suspended sediment transport in the Gulf of Lion (NW Mediterranean): impact of extreme storms and floods. Continental Shelf Research, this issue, doi:10.1016/ j.csr.2008.01.015.

Ulses, C., Estournel, C., Puig, P., Durrieu de Madron, X., Marsaleix, P., 2008c. Dense shelf water cascading in the northwestern Mediterranean during the cold winter 2005. Quantification of the export through the Gulf of Lion and the Catalan margin. Geophysical Research Letter, in press.

Urick, R.J., 1975. Principles of Underwater Sound. McGraw-Hill, NY, 384pp.

Wiberg, P.L., Drake, D.E., Cacchione, D.A., 1994. Sediment resuspension and bed armoring during high bottom stress events on the northern California inner continental shelf: measurements and predictions. Continental Shelf Research 14 (10/11), 1191-1219. 